Document downloaded from:

http://hdl.handle.net/10251/60130

This paper must be cited as:

Moragues, JJ.; Paya-Zaforteza, I.; Medina, O.; Adam Martínez, JM. (2015). Eduardo Torroja's Zarzuela Racecourse grandstand: Design, construction, evolution and critical assessment from the Structural Art perspective. Engineering Structures. 105:186-196. doi:10.1016/j.engstruct.2015.10.008.

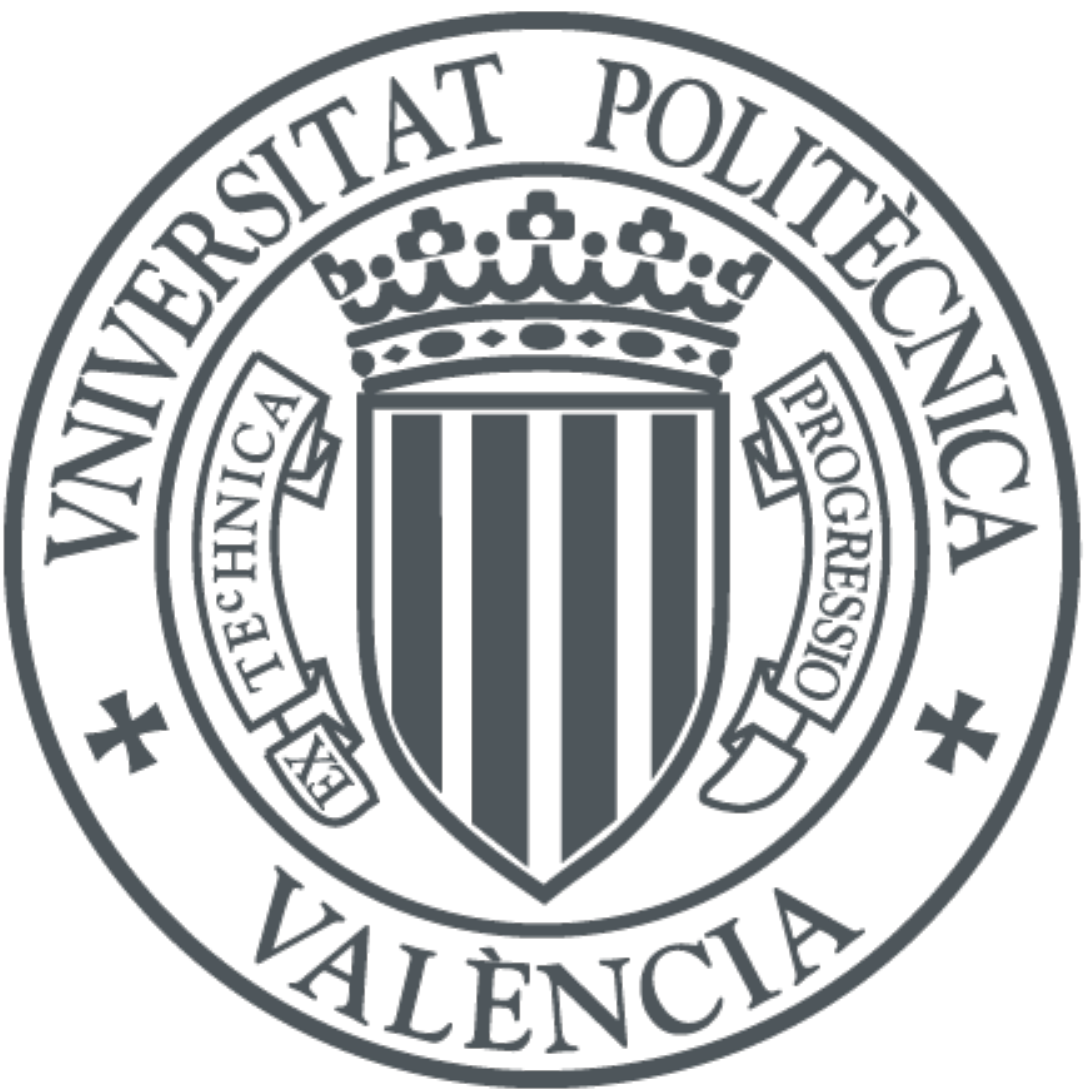

The final publication is available at

http://dx.doi.org/10.1016/j.engstruct.2015.10.008

Copyright Elsevier

Additional Information 


\title{
Eduardo Torroja's Zarzuela Racecourse grandstand: design, construction, evolution and critical assessment from the Structural Art perspective
}

Juan J. Moragues, Ignacio Paya-Zaforteza, Oswaldo Medina, Jose M. Adam*

ICITECH, Universitat Politècnica de València. Camino de Vera s/n, 46022 Valencia, Spain

*Corresponding author: E-mail: joadmar@upv.es; tel.: +34 963877562; fax: +34 963877568

\begin{abstract}
The grandstands of La Zarzuela Racecourse in Madrid designed by the engineer E. Torroja and the architects $C$. Arniches and M. Dominguez are one of the world's most outstanding concrete constructions of the first half of the 20th century. This paper describes the design competition and the conceptual design process that led to their construction and carries out a critical assessment of the grandstands from the perspective of Structural Art. By doing so, the paper helps to develop the discipline of structural criticism, and points out lessons learned from their design and construction process which should not be forgotten at the present time, such as: (a) the importance of design competitions; (b) the fact that the pursuit of economy and efficiency can actually improve the quality and aesthetics of the design; (c) the importance of combining logical reasoning based on technical criteria with imagination to achieve excellence in structural design; and (d) the importance of estimating structural behavior by simple formulas and of learning from both existing structures and experimental models.
\end{abstract}

Keywords: Eduardo Torroja; thin-shell; structural art; reinforced concrete; assessment 


\section{Introduction}

Eduardo Torroja (1899-1961) was one of the most outstanding Spanish engineers of the $20^{\text {th }}$ century [1]. Although Torroja was especially renowned for his thin-shell roof structures, he also designed a wide variety of projects such as aqueducts, hangars, factories, churches and water storage tanks, using a combination of different structural systems such as beams, arches, thinshells or ties [2,3]. Torroja himself explained his structural philosophy and chief works in his two major books: "The structures of Eduardo Torroja: an autobiography of engineering accomplishment" [2] and "Philosophy of structures" [4].

In 1934, with a group of engineers and architects, Torroja co-founded a private research institute, the Instituto Técnico de la Construcción y de la Edificación (Technical Institute for Construction and Building), which in 1946 was incorporated into the Spanish Council for Scientific Research and in 1949 merged with the Instituto del Cemento (Cement Institute) to create the Instituto Técnico de la Construcción y del Cemento (Construction and Cement Technical Institute). Torroja was made the director of the new Institute and turned it into one of the world's leading construction research groups. He also used it to transmit his personal style of working, based on combining research with practice and knowledge transfer. He died in his office in June 1961, since then the Institute is called in his honor the Instituto de Ciencias de la Construcción Eduardo Torroja (Eduardo Torroja Institute for Construction Science) [5].

Torroja's works are now a part of the architectural and cultural heritage and as such have been the subject of many studies [6,7]. However, the analysis of his work from the perspective of the structural engineer based on the original documentation of his projects is much rarer, being worthy of mention the recent studies on the Recoletos roof $[8,9]$ and on the San Nicolas Church [10].

Within this context, this paper delves into the conceptual design process and the design competition that led to the construction of one of Torroja's most important works: the grandstand at the La Zarzuela Racecourse in Madrid (Figures 1 and 2). In addition, the paper also provides an assessment of the grandstand from the Structural Art perspective, in an attempt to explain the importance of the work in the history of structural engineering and to contribute to the development of the discipline of structural criticism. This type of study is of major importance today, as has been pointed out by Schlaich [11], Hu et al. [12] and Addis [13], among others. For example, Schlaich [11] has argued that structural engineers should be able to express their opinions about others' work and should also open-mindedly accept criticism from others. This would help the general public to become aware that the structures of buildings and bridges are an "inseparable part of our culture and that their quality is an indication of the public interest they attract and of the dedication of the engineers entrusted with their design". Hu et al. [12] have identified the key conditions that have contributed to the creation of works of Structural Art and have shown how the recognition of the concept of Structural Art with the help of education and certain practices can inspire, instill an aesthetic motivation, and improve future designs. Addis [13] has discussed the role of criticism and aesthetics in developing an opinion of what is good structural design and supports the idea of criticism being an important part in engineer's formation. According to Addis [13], this formation in criticism should continue well beyond graduation. Another goal of the paper is to 
contribute to better public awareness of Torroja's work and structural philosophy, as a way of keeping alive and spreading his invaluable technical and scientific legacy. In this context, the present study is aligned with similar studies carried out by other authors on the work of Gustav Eiffel [14], Pier L. Nervi [15], Félix Candela [16, 17], Hilario Candela [18], Othmar Ammann [19], 18th century and Arab engineers [20], and Roman engineers [21].

The present study is the result of: (a) a bibliographic review that included the original design documents, (b) site inspections, and (c) interviews with those responsible for the recent renovation of the Racecourse and with the people in charge of its management. The study is divided as follows. Section 2 looks at the circumstances that led to the project and the building of the La Zarzuela Racecourse. Section 3 examines the most important aspects of Torroja's design, including the loading test carried out on the roof, and looks at the main aspects of the racecourse's construction. Section 4 describes the repair of the roof shell carried out in 2008 while Section 5 contains an assessment of the structure from the Structural Art standpoint. Finally, we give the main conclusions we derived from this study in Section 6.

\section{La Zarzuela Racecourse design competition}

\subsection{Background}

La Zarzuela Racecourse was the result of a fashion for racecourse construction in Europe at the end of the $19^{\text {th }}$ and beginning of the $20^{\text {th }}$ century. At that time, there were seven racecourses in Spain at which races frequently took place: these included Madrid, Seville, Granada, Barcelona, Santander, San Sebastián and Aranjuez, most of which were built with the support of the Spanish royal family. Madrid's racecourse was known as the Hipódromo de La Castellana and was opened on January $31^{\text {st }} 1878$ on the occasion of the marriage of Alfonso XII and María de las Mercedes de Orleáns-y-Borbón. It replaced the previous facilities of Alameda de Osuna (1835), Casa Blanca (1843) and the Casa de Campo (1845).

In 1930 the architects Secundino Zuazo and Hermann Jansen won an international competition to draw up a city plan for Madrid, which included the construction of a major new avenue, the Paseo de la Castellana. As the existing racecourse proved to be an obstacle to the new boulevard it was demolished in 1933. Horse racing then mainly took place at the Aranjuez racecourse (built in 1919 on land owned by the Spanish royal family) and at the San Sebastian racecourse (built in 1916).

While the old racecourse was being demolished, the authorities started to search for a suitable location for a new one and finally a site was chosen in the Monte del Pardo. However, this decision caused some controversy, since it was a place of extraordinary natural beauty and people feared the building of a racecourse there would spell the end of its forest [22].The proposed site was finally approved, after visiting some of Europe's leading racecourses, such as Longchamps, or Auteuil, built in the Bois de Boulogne in Paris, which was used as a model for the new racecourse in Madrid. 


\subsection{Spanish Design Competition}

On July 28th 1934, the Gabinete Técnico de Accesos y Extrarradio, a public agency, which among other responsibilities, was dedicated to finding solutions to the town planning problems in Madrid's outskirts, announced a public competition among Spanish architects for Madrid's new racecourse [23]. Tendering specifications took into account the environmental value of the site and specified the main topographical data for the project. These specifications had been drawn up by the association in charge of regulating horse racing in Spain (the Sociedad de Fomento de la Cría Caballar de España) together with the Spanish horse riding association (the Sociedad Hípica Española). The budget for the work (including buildings, all facilities, infrastructure, architects' fees, engineers' fees and on-site supervision) was limited to 3,000,000 Spanish pesetas.

The deadline for submitting entries to the competition was October $1^{\text {st }} 1934$. Nine proposals were submitted (see Figure 3), all of them signed by architects and six of which had engaged engineers to help in the design of the required structures. Torroja was the engineer in the proposal submitted by the architects Carlos Arniches and Martín Domínguez.

All the designers approached the challenge of building the racecourse as a problem of global planning, land-use management and integration into the landscape of El Monte de El Pardo [24]. All their solutions proposed building covered and uncovered stands for the public at the races, with the easiest possible access and a clear view of the racing. The structural solutions included reinforced concrete transverse portal frames spaced between 5 and 6 meters, with betting areas and accesses under the terraced stands and large cantilever beams of varying thickness [7].

At that time, reinforced concrete was considered a modern material that was cheap to use, did not need highly skilled workmen to apply and suitable for sizeable projects. Even though it still had not found universal favor with architects [25], it was chosen as the building material by all the contestants. In some cases, the external concrete surface was given a bush-hammered finish [25], in others it was given a granite or fine brick facing [26], but in most cases it was either painted or left in its natural state when the formwork was removed.

The structural solution of the cantilever beam that covered the stand was in large measure the key to each of the proposals. In most of these the beam was supported by a rear column resting on the foundations. However, Arniches, Domínguez and Torroja, and Gutierrez Soto and Fernández Conde proposed counterbalancing the cantilever beam with a tie member anchored on the slab of the top promenade, which took the form of a cantilever in the latter proposal, while Arniches, Domínguez and Torroja supported the slab on a rear column (see Figure 3).

The competing projects were judged in December 1934 and the winner was the proposal of the architects Carlos Arniches and Martín Domínguez with the assistance of engineer Eduardo Torroja, based on the San Siro racecourse in Milan, for its elegance, daring and well balanced architectural-structural solution [27]. 


\section{Torroja's design}

The project competition requirements as outlined in the bidding conditions called for three stands, North, Central and South, 55, 25 and $55 \mathrm{~m}$ long, respectively. Their structure was based on reinforced concrete transverse portal frames spaced every $5 \mathrm{~m}$. The winning bid (Figure 4) was based on the development of additional features over and above the competition's basic requirements (Figure 5). After winning the project, Torroja introduced a series of modifications which were included in the finished construction (Figure 6) [28].

Each of the reinforced concrete transverse portal frames was designed in two parts:

(a) The stand structure, consisting of a set of beams and columns supporting the terraces over the service area, which gives stability to the entire construction.

(b) The roof over the grandstand and rear terrace, with its tie member (Figure 6).

The conceptual design of both these elements is described below.

\subsection{Structure of the grandstands}

Torroja justified the evolution from the original straight lines (Figure 5) of both the grandstand beams and those of the rear terraces to their final curved shapes (Figures. 4 and 6) because "the appropriateness of leaving as much space as possible in these galleries and the appropriateness of achieving structural shapes of certain aesthetic value led to curved lines" [28]. In his structural solution to the grandstands he shows his way of understanding reinforced concrete structures: clarity of function, simple construction, the absence of unnecessary elements, and a care for correct behavior through time.

The whole structure rests on two supports, I and ABF (Figure 6). The high stiffness of the former, located in the zone with access to the racecourse, allows a hinge to be placed at the top and bottom of the column. This setup simultaneously gives the whole system the necessary stability, lightness and flexibility to allow for thermal and rheological (i.e. creep and shrinkage) expansion and contraction. The central column, ABF, supports both top of the stands beam and the floor slab of the top promenade (Figures 5 and 6). Besides, the narrowest part at the center of the stands beam coincides with a construction joint in the concrete to reduce second-order forces due to concrete shrinkage.

Of special interest is the balance between the weight of the top promenade and that of the roof. By means of a simple tie member, Torroja uses the weight of the gallery to provide stability and avoid the overturning of the roof, which in this way is hinged on the principal support $A B F$, so that the grandstand solution is analyzed differently to the rest of the structure.

The position of the staff gangway (named HG in Figure 6), which overhangs the main support, is possible thanks to its small size and the support's dimensions, and emphasizes the lightness of the structural solution.

The resulting simplified structure for the analysis of the stands is a single span RC frame with a curved intrados and variable depth beam (Figure 7). Torroja used the Muller-Breslau method 
to analyze this frame, which is subjected to its self-weight plus the usual live loads considered at that time [28].

Between each two transverse portal frames, which are separated by 5 meters, there is a toroidal vault $5 \mathrm{~cm}$ thick. The low longitudinal stiffness of this vault allows it to adapt itself perfectly to small deformations of the portals due e.g. to thermal movements, creep or shrinkage, but it does not contribute enough to longitudinal stability. Neither does the roof shell improve this longitudinal behavior, so that Torroja introduced a transverse beam (marked as B in Figure 6) which was very stiff between the central portal frames and less stiff towards the outer portal frames to allow for the free contraction and expansion of the whole structure.

\subsection{Roof structure}

The element that best represents Torroja's philosophy is the roof of La Zarzuela racecourse, and the solution he arrived at bears witness to his knowledge of concrete structures and his practical approach. His collaboration with the architects Arniches and Dominguez contributes the final touch of elegance and artistry.

The winning entry in the competition (Figure 4) consisted of a large variable thickness cantilever beam in each transverse frame, resting on the central support and anchored on the rear tie member. Between each beam were cylindrical vaults of circular directrix, $6 \mathrm{~cm}$ thick and reinforced on top by $20 \times 10 \mathrm{~cm}$ ribs, which did not reach the main beams (Figure 4). The rise of the circular vaults was $55 \mathrm{~cm}$ and the thrust of each vault was balanced by the neighboring vault except at the end of each stand where Torroja designed a stiff structure which he called the "end body", to give stability to the whole building.

However, this solution involved the following drawbacks:

(a) The presence of a main beam and a ribbed vault meant that concrete had to be poured in three phases.

(b) Since stability depended on the entire structure, the formwork had to be kept in place during the entire construction process of each grandstand.

(c) It was difficult to achieve rainfall runoff from the roof.

The final solution he came up with (Figure 6) solved these problems and at the same time conserved the circular arches at the front of the roof shell, with which Torroja had won the competition. This solution consisted of a hyperbolic vertical cross section with polygonal lateral boundaries. In each of the vertical roof sections, these three lines define three points on a circumference, with the sum of all the circumferences outlining the surface of the roof [27].

Torroja defined the roof by transverse vertical sections (Figure 8) [29]. The roof's front section had a rise of $50 \mathrm{~cm}$ and a radius of $6.70 \mathrm{~m}$, while the section over the support had a rise of 1.40 $\mathrm{m}$ and a curvature radius of $2.75 \mathrm{~m}$. In the central transverse section between the roof supports, its thickness ranges between $5 \mathrm{~cm}$ at the end and $15 \mathrm{~cm}$ at the supporting section and is again reduced to $6 \mathrm{~cm}$ at the opposite end (Figure 8). On the supports' cross section the roof thickness is $9 \mathrm{~cm}$ at the outside of the cantilever, $73 \mathrm{~cm}$ over the support and $6 \mathrm{~cm}$ at the 
other end (Figure 8). The cantilever length is $12.67 \mathrm{~m}$ and the total length of the roof is 19.60 $\mathrm{m}$.

The analysis and construction of the shell was divided into basic structural elements formed by the main column, its corresponding tie member and two half-hyperboloids, which Torroja called lobes (Figure 9) [29]. Each of these elements was stable and could be built independently. Each of the lobes was built in a single stage and their boundaries were the construction joint located at the top of the shell, which was the zone with the smallest loads and least permeable to water (Figures 9 and 10). To ensure that the entire structure was leveled, the construction joint between two lobes was pierced with rebars. The shell itself had no ribs and the rainwater was channeled towards a drainpipe in the central support. In appearance, it had a wave-like surface with arches over the supports and reduced curvature at both extremes [30].

Although the shape of the roof in this design (in which the function of the $12.67 \mathrm{~m}$ as a cantilever is much more important than the transversal work between the columns) is strong enough to resist the structural problem considered, the following questions should be borne in mind:

(a) It is impossible for the roof to function solely as a membrane, so that stresses perpendicular to the shell's mid-plane appear.

(b) Given the shape of the cross section of the cantilever, parallel tangential forces also appear at the mid-plane of the shell, besides the vertical shear forces of a beam

(c) In the proximity of the columns, the singularity of the stress distribution is very important.

For the above reasons, it was impossible to carry out an exact analysis of the structure and Torroja decided to carry out a simplified analysis [28] that considered three different roof areas: the roof far away from the column $A B F$ and the tie $C D$, the areas of the roof close to the column $A B F$ and the joint between the tie $C D$ and the roof. Torroja obtained the internal forces in the sections far from the supports considering the roof as a cantilever and then he used the Vening-Meinesz's integral to obtain the stresses. By doing so, Torroja obtained the approximate tensile isolines for the sections away from the supports and so be able to position the rebars along them, with the intention of later testing a scale model of the roof to discover more about its behavior. In addition to the approximate cantilever analysis model, he studied the section's transverse bending in order to modify the distribution of the rebars around the main support and the tie member, and thus was able to obtain the distribution of the rebars for each lobe (Figure 10).

\subsection{Testing of the roof structure}

Due to the uncertainty surrounding the results of the analysis, Torroja proposed to carry out tests on a scale model of the structure. However, the building company in charge of the project (Agromán) preferred to test a complete full-scale lobe, as they considered it would give more reliable results and at the same time they could also check the wooden formwork. The lobe was tested to failure by piling sacks of earth directly on top of the concrete surface with a crane (Figure 11). The mean self-weight of the lobe was $2.80 \mathrm{kN} / \mathrm{m}^{2}$, the theoretical loads 
attributable to snow and vertical wind component was $0.70 \mathrm{kN} / \mathrm{m}^{2}$. The lobe failed under test at a total live load of $6.05 \mathrm{kN} / \mathrm{m}^{2}, 2.5$ times greater than its total load (self-weight plus live loads) and 8.6 times higher than its theoretical live load value [28].

The available records of this test show that:

(a) The structure behaved elastically with a maximum deflection of $15 \mathrm{~cm}$ at the highest point and maximum deformation at both ends of the shell, which were unsupported by contiguous lobes [28].

(b) The roof seems to have failed by compression of the concrete around the central column. The failure mode was fragile with little deformation involved $[7,28]$.

(c) None of the rebars was seen to yield and so they were reused in the actual construction of the roof.

With the guarantees provided by the analytical calculations and the practical tests, it was decided to go ahead with the project without any further modifications.

\subsection{Construction and evolution}

The final project was approved on 17 September 1935 and work on the racecourse started at the end of that year. With an initial budget of $3 \mathrm{~m}$ pesetas $(€ 18,000)$, the later stages of the work were interrupted by the Spanish Civil War. When the war was over, work was restarted, but as the racecourse had been used as a battle front during the conflict, the damage sustained by the unfinished buildings also had to be repaired, especially the holes, the many cracks and warping of the flexible roof caused by shellfire [28]. As well as repairing this damage, the opportunity was also taken to strengthen the end sections of the shell, which were seen to have been deformed much more than the central sections, due to the absence of a supporting contiguous lobe. This reinforcement consisted of installing five diagonal ribs on the upper surface of the shell.

The racecourse, complete with all the ancillary services necessary for its functioning, was inaugurated in May 1941, and has been in service since that time, with the exception of the period between November 1996 and September 2003.

The project drawn up by Arniches, Domínguez and Torroja was awarded the National Architecture Prize, and the grandstand, considered to be a work of engineering art, was declared an Asset of Cultural Value (Bien de Interés Cultural in Spanish) by the Spanish Ministry of Culture on 16 October 2009, after a lengthy period of deliberation which had begun in 1980. The racecourse now belongs to the Spanish State and is consequently part of the National Heritage.

\section{Repairing works on the roof shell}

Throughout the years the different racecourse buildings have been adapted to meet changing requirement and occasional damp patches and cracks, which left the rebars open to view, were observed in the roof shell [7]. 
In 2003, a competition was announced for the "Restoration and Renovation Project of the Zarzuela Racecourse in Madrid", with the idea of adapting the facilities to modern-day needs and renovating the concrete buildings to restore them as far as possible to their original aspect as conceived by Arniches, Domínguez and Torroja. The project was awarded to Junquera Arquitectos S.L.P. in conjunction with the engineering office Carlos Fernandez Casado S.L. [30]. In the study of the evolution of carbonation and corrosion in the concrete, those responsible for the project collaborated with the Eduardo Torroja Institute [31]. The work was begun in 2008 by the Dragados S.A. construction company and after finishing received the first prize of the Madrid Architects Association in 2012.

In spite of the considerable period of time that had passed since its inauguration, the condition of the laminar structures at the start of the $21^{\text {st }}$ century was found to be reasonably good. The damage found during the inspections carried out was similar to that usually found in reinforced concrete structures built in the middle of the $20^{\text {th }}$ century and included carbonation, corrosion of the reinforcement and various types of structural and rheological cracks, though it was not found to have significantly affected structural safety [30].

The restoration consisted essentially of repairing the damaged concrete and reinforcement in the most affected areas after removing the paint from the underside of the concrete and the waterproofing from the upper surface. These areas were then re-covered with a special mortar and all the cracks were sealed. The underside was finished with mortar that simulated the original finish in the form of wooden formwork boards. A system of permanent sensors was installed to monitor the qualitative evolution of the risk of reinforcement corrosion and thus be able to foresee future maintenance needs. Figure 12 shows two images of the restoration works.

The stands and roofs were then painted white, as can be seen in Figure 1.

\section{Critical assessment from the Structural Art point of view}

According to Billington [1] the best works of structural engineering become pieces of Structural Art when they meet the ideals of efficiency, economy and elegance. Economy is the analysis of the costs of the structure as compared with society's idea of the usefulness of the forms and is also the social dimension of the structure as related to the proper use of public and private money. Efficiency means the making of safe and durable structures with the minimum amount of materials. It is related to the conservation of natural resources and defines the scientific dimension of the structure. Finally, elegance refers to the search for the maximum aesthetic expression within the constraints set by economy and efficiency and defines the symbolic dimension of the structure.

The following paragraphs contain a critical assessment of La Zarzuela Racecourse grandstand based on the above three ideals, and aim to show that the building is an outstanding example of Structural Art. The analysis focuses mainly on the roof, as it forms La Zarzuela's most singular and characteristic element. 


\subsection{Evaluation of efficiency and economy}

The economy and efficiency of the final design can be shown by a comparison with both Torroja's initial design (see Figure 4) and the other proposals submitted to the design competition (see Figure 3). Among these proposals, the entry by F. Heredero, J. Golfín and C. Fernández-Casado (see Figure 3) deserves special attention, as Fernández-Casado was one of the most brilliant Spanish structural engineers at that time. He proposed a system of one-way floor slabs supported by transverse stiffening ribs and longitudinal beams with a depth that varied according to their internal forces. Table 1 shows the volume of concrete and the amount of formwork required to build a full roof module and one linear meter of roof for all the solutions. The following comments can be done:

- Torroja's final design required 5.6\% more concrete than his initial design, but far less formwork ( $47 \%$ less). In addition, and as explained in Section 3.2, each of the roof lobes of the final design could be built independently, which meant that formwork could be reused. This was an additional great advantage over his initial design, which required the whole roof to be built in a single process to ensure its safety, due to the thrusts exerted by the cylindrical vaults included in the initial design.

- Torroja's final design also had clear advantages over Fernández-Casado's proposal, as it required $27 \%$ less concrete and $62 \%$ less formwork. Note that a formwork with a complex form such as the one used by Torroja is more expensive per unit of formwork surface than a planar formwork such as the one required to build Fernández-Casado's proposal but Torroja decreased the importance of this higher cost by reusing the formwork. Note also that using less concrete also implies a lighter roof and smaller foundations.

Other points in favor of the goodness of Torroja's final design are:

- Torroja's final roof design uses very small quantities of materials. According to the drawings published in Torroja [29], the cantilevered part of the roof has a typical thickness that varies between 6 and $14 \mathrm{~cm}$, with an approximate average value of $11 \mathrm{~cm}$ (note that these thicknesses increase locally along the support axis). Considering that the cantilever spans $12.67 \mathrm{~m}$ this gives a remarkable average typical span-to-thickness ratio of 115/1. This was possible because Torroja designed a doubly-curved structure with a form that works three-dimensionally. This was not the case with other notable cantilevered roofs designed at that time. For example, the celebrated grandstands of Nervi's Stadio Artemio Franchi, described in Desideri et al. [32] and finished in 1932 in Florence (Italy), are defined by planar reinforced concrete frames placed every $4.76 \mathrm{~m}$, a distance very close to the $5 \mathrm{~m}$ separation adopted by Torroja for his transverse portal frames. Nervi's concrete frames support one-way floor slabs defining the roof, so that all the structural elements are planar. As a result, the girders defining the cantilever roof have an approximate average thickness of $1.4 \mathrm{~m}$ for a cantilever span of circa $14.6 \mathrm{~m}$. The average typical spanto-thickness ratio is therefore $10.4 / 1$, i.e. Nervi's structure is much less slender and probably needed larger quantities of materials.

- Torroja made use of a doubly-curved surface in different elements, such as the cantilevered roof of the betting hall and adapted the shape of the structural elements, such as the main support and the roof or the staff gangway to the existing internal forces. 
- The transverse portal frames that support the stands are a very successful trade-off between the stiffness required to withstand wind forces and the flexibility required to decrease internal forces due to temperature changes and concrete shrinkage. This frame design thus ensures the safety of the structure while keeping internal forces as low as possible. In fact, Torroja explicitly emphasized the ideas of economy and efficiency when he described the behavior of the grandstand frames in [2].

- The authors did not find any evidence of cost overruns during the construction of the racecourse. On the contrary, economy seems to have been a considerable constraint, as proved by the fact that the reinforcing bars and the formwork used in the real scale model of the roof (see Section 3.3) were reused after the model had failed under the loading test.

- Torroja placed the construction joints in the final design along the crown of the roof lobes which reduced the danger of water seepage to a minimum, made drainage of the rainfall easier and increased the durability of the structure.

Finally, as has been pointed out by Paya-Zaforteza [33], it must be remembered that economy should take into account the cost of maintaining the structure throughout its entire life cycle and not only the cost of its construction. From this perspective, Torroja's design is also clearly outstanding, as it has been in service without any major renovation work for near seventy years, apart from the repair of the damage it sustained during the Spanish Civil War (1936-39). The remarkable durability of the roof is exceptional, as it was designed and built at a time when the ideas of durability, life cycle and sustainability were not explicitly included in the codes and did not form part of the training of engineering students.

\subsection{Evaluation of its aesthetic qualities}

As the elegance of a structure is a subjective parameter, it is not easy to assess. In the present paper, following in the steps of previous studies [10, 14], the aesthetic qualities of the structure are assessed according to the following perspectives: (1) the aesthetic objectives of the designers; (2) the critical acclaim received; and (3) a visual analysis.

Torroja had a clear aesthetic objective in designing the grandstands. For example, when he described the process he used to define the shape of the roof, he stated that he rejected the initial solution of a flat slab supported by strengthening ribs hidden on the upper surface because "it seemed heavy and unaesthetic", then he tried using a conoid, but this was also discarded because "it was not very attractive" [2]. Later, when the decision to use a hyperboloid was taken, the shape was slightly modified, as Torroja did not want the lines of intersection of the hyperboloids to curve downwards, because they would be "less agreeable to the eye, or would at least be too startling to observers accustomed to a more classical expression" [2]. He also openly criticized the design, when he referred to the arcades which seem to support the lower part of the stands (see Figure 1), describes them as false and apparently added for reasons unrelated to the basic purpose of the design. According to Lapunzina [34] these arcades seem to be the contribution of the architects. Finally, when Torroja describes the structure that supports the stands, he states that it was designed to "convey the maximum sense of spaciousness at the lower floor level" and that "it provides a 
harmonious proportion between the volumes of the large betting hall and the gallery beneath the stands".

The grandstands have received high praise from engineers, architects and art historians. Some of their opinions are, briefly: Billington [1] praised Torroja's style in his seminal book on Structural Art and considers La Zarzuela as one of Torroja's three major works, a work that emphasizes smooth rib less surfaces which clearly express their thinness. Lapunzina's book on the architecture of Spain describes La Zarzuela's shells as elegant and audacious and remarks that the image of the building "relied entirely on the elegance and audacity of the structural solution". Lapunzina also comments that the use of a bare concrete shell as the image of an official building was an additional major innovation. The racecourse has been included in the catalogue published by the Fundación Docomomo [35], an international association dedicated to the protection and conservation of examples of modern architecture and town planning. This catalogue states that the overall racecourse project is very well integrated into the natural environment and perfectly fits the site conditions. It also remarks that the innovative and bold grandstands form the element that attracts general interest and international recognition. Similarly, Lahuerta [36] considers that the Zarzuela roof has an extraordinary volatility and thinness that gives the building the strongest expression. This author claims that Torroja's design reached an "absolute equality of structure, material, function and form" that enabled him to create an undoubted paradigm. But above all, its roof is the center of attraction and adds value to the environs. It is popular with both the race-goers and those who rent the venue for special events, the engineering and architecture students from all around the world that visit the building as a part of field trips (Polo, [37]) and even by the racing community, which has described La Zarzuela as "one of the most beautiful racecourses in the world" (Higgins [38]). As we can see, there is general agreement on the outstanding esthetic qualities and high degree of architectural achievement of La Zarzuela Racecourse.

Torroja's solution blends in almost perfectly with the neighboring landscape of the Pardo Hill, in spite of the initial doubts about the visual effects of a racecourse on the surrounding landscape. The smooth elegant curves of the grandstand structures, the somewhat aggressive tone of the project itself, are a perfect response to the undulations of the surrounding hills, with the rugged peaks of the Guadarrama Mountains acting as a backdrop. In fact, these stands, without altering the view of the Pardo Hill from the city, give a different vision of the north of Madrid, with its gentle slopes running down to the Manzanares river, with which the dramatic roof shells with the gradual reduction in their curves as they travel outwards almost seem to join.

Finally, it is also important to realize that, although the roof is the more spectacular element of the building, the stands, the roof and the interior of the building define a perfect ensemble due to the harmonious formal and structural relationship among all the elements. For example, the doubly curved surfaces of the roof (see Fig. 1) have their counterpart in the doubly curved surfaces that cover the betting hall and the gallery that provides access to the stands (see Fig. 2). Similarly, the tie and the main support have a fundamental structural role, but they also have an additional important and subtle function: they connect the roof, the stands, and the interior spaces making the observer become aware that all these elements are integrated into a single element which acquires an outstanding value: the building. 


\section{Conclusions}

This paper describes the design competition and the conceptual design process that led to the construction of one of Torroja's major works: the grandstand of the Zarzuela Racecourse in Madrid. It also assesses the grandstand from the perspective of Structural Art in order to further the development of the discipline of structural criticism, and aims to explain the major importance of the work in the history of structural engineering.

The grandstands are a perfect expression of Torroja's ideals as summarized by himself when he wrote: "My final aim has always been for the functional, structural and aesthetic aspects of a project to present an integrated whole, both in essence and appearance" [2]. But the detailed analysis of the design process and construction of the grandstands also provide lessons which should not be forgotten at the present time, such as: (a) the importance of design competitions when projects have to be carried out with limited budgets; (b) the fact that the pursuit of economy and efficiency can actually improve the quality of the design and does not necessarily mean poor structures; (c) the importance of combining logical reasoning based on technical criteria with imagination to achieve excellence in structural design; and (d) the importance of estimating structural behavior by simple formulas and of learning from both existing structures and experimental models. All these considerations make Torroja's design and approach an example to engineers and architects of all ages.

\section{Acknowledgements}

The authors are very grateful to the engineers G. Ayuso and L. Fernández Troyano from Carlos Fernández Casado S.L. and C. Polo from the company Hipódromo de La Zarzuela S.A. for all the information and support provided. The authors also want to thank the Archivo Torroja and its former librarian, I. García, for providing full access to the funds of the archive to develop this research. Funding for this research was provided by the Spanish Ministry for Science and Innovation (Research Project BIA 2011-27104).

\section{References.}

[1] Billington DP. The Tower and the Bridge: the New Art of Structural Engineering, Princeton University Press, Princeton, 1985.

[2] Torroja E. The structures of Eduardo Torroja: an autobiography of engineering accomplishment, Dodge Corporation, New York, 1958.

[3] Fernández-Ordóñez JA, Navarro-Vera JR. Eduardo Torroja Ingeniero- Engineer. Pronaos, Madrid, 1999. Bilingual edition in Spanish-English.

[4] Torroja E. Philosophy of structures, University of California Press, Berkeley, 1958. 
[5] Cassinello P. Eduardo Torroja y la industrialización de la "machine à habiter" 1949-1961. Eduardo Torroja and the industrialization of the "machine à habiter", Informes de la Construcción 2008; 60(512): 5-18. [In Spanish]

[6] Jordá C. Eduardo Torroja, la vigencia de un legado. Eduardo Torroja, the validity of a legacy. Universidad Politécnica de Valencia, Valencia, 2002. [In Spanish]

[7] Antuña J. Las estructuras de edificación de Eduardo Torroja Miret. Eduardo Torroja Miret's building structures. Ph.D. dissertation. Universidad Politécnica de Madrid, Madrid, 2002. [In Spanish]

[8] Lozano-Galant JA, Paya-Zaforteza I. Structural analysis of Eduardo Torroja's Frontón de Recoletos' roof. Engineering Structures 2011; 33(1): 843-54.

[9] Cabello A, Paya-Zaforteza I, Adam JM. Non-linear analysis of Eduardo Torroja's Frontón de Recoletos' roof using a discrete reinforcement approach. Engineering Structures 2014; 80: 406417.

[10] Nuñez-Collado G, Garzón-Roca J, Paya-Zaforteza I, Adam JM. The San Nicolas Church in Gandia (Spain) or how Eduardo Torroja devised a new, innovative and sustainable structural system for long-span roofs. Engineering Structures 2013; 56: 1893-1904.

[11] Schlaich J. On the conceptual design of structures - an introduction, In Proc. of the IASS Int. Symp. "Conceptual design of Structures" Vol. 1, Institut für Konstruktion und Entwurf II, Stuttgart, 1996, pp. 15-25.

[12] Hu N, Feng P, Dai G-L. Structural art: Past, present and future. Engineering Structures 15; 79: 407-416,

[13] Addis B. Free will and determinism in the conception of structures - A discussion of the art of the Structural Engineer". In Proc. of the IASS Int. Symp. "Conceptual design of Structures" Vol. 1, Institut für Konstruktion und Entwurf II, Stuttgart, 1996, pp. 29-36.

[14] Thrall AP, Bréa KL, Billington DP. The Maria Pia Bridge: A Major Work of Structural Art. Engineering Structures 2012; 40: 479-486.

[15] Cresciania M, Forth J. Three Resilient Megastructures by Pier Luigi Nervi. Int. Journal of Architectural Heritage: Conservation, Analysis and Restoration 2014; 8(1): 49-73.

[16] Garlock MEM, Billington DP. Félix Candela: Engineer, Builder, Structural Artist, Yale University Press, New Haven, 2008.

[17] Burger N, Billington DP. Felix Candela, elegance and endurance: an examination of the Xochimilco shell. J Int Assoc Shell Spatial Struct 2006; 152: 271.

[18] Adriaenssens S, Brown N, Lowinger R, Hernandez J. Structural Analysis of Reinforced Concrete Folded Hyperbolic Paraboloid: a case study of the Modern Miami Marine Stadium. Int. Journal of Architectural Heritage: Conservation, Analysis and Restoration 2014; 8(4): 498516. 
[19] Thrall A, Billington D. Bayonne Bridge: the work of Othmar Ammann, Master Builder. Journal of Bridge Engineering 2008; 13: 635-43.

[20] Suarez FJ, Bravo R. Historical and probabilistic structural analysis of the Royal ditch aqueduct in the Alhambra (Granada). Journal of Cultural Heritage 2014; 15(5): 499-510.

[21] Mehrotra A, Glisic B. Reconstruction of the appearance and structural system of Trajan's bridge. Journal of Cultural Heritage 2015; 16(1): 65-72.

[22] Torroja E, García Reyes E. El nuevo hipódromo de Madrid. Antecedentes de un concurso. Madrid's new hippodrome: background of a design competition. Hormigón y Acero 1934; 7: 287-288. [In Spanish]

[23] García Mercadal F. Métodos de trabajo. Después de un concurso. Cómo se hizo un proyecto. Working methodology after the design competition: how the Project was done. Hormigón y Acero 1934; 7: 289-297. [In Spanish]

[24] Ulargui S. Proyecto del Arquitecto S. Ulargui, Design of the architect S. Ulargui. Hormigón y Acero 1934; 7: 298-302. [In Spanish]

[25] Heredero F, Golfín JF, Fernández-Casado C. El Nuevo Hipódromo de Madrid. Proyecto de los arquitectos F. Heredero y J.F. Golfín. Ingeniero C. Fernández Casado, Madrid's new hippodrome: design by the architects F. Heredero and J.F. Golfín. Carlos Fernández Casado engineer. Hormigón y Acero 1934; 7: 332-339. [In Spanish]

[26] Bans Ochoa O, Rodríguez S. El Nuevo Hipódromo de Madrid. Proyecto del arquitecto O. Bans Ochoa y del ingeniero S. Rodríguez. The New Hippodrom of Madrid's new hippodrome: design by the architect O. Bans Ochoa and the engineer S. Rodríguez. Hormigón y Acero 1934; 7: 347-354 [In Spanish]

[27] Arniches C, Dominguez M, Torroja E. El Nuevo Hipódromo de Madrid. Proyecto de los arquitectos Arniches y Dominguez. Madrid's new hippodrome: design by the architects $C$. Arniches and M. Dominguez and the engineer E. Torroja. Hormigón y Acero 1934; 7: 303-311. [In Spanish]

[28] Torroja E. Estructura de las Tribunas del Nuevo Hipódromo de Madrid. Structure of the grandstands for the New Hippodrome of Madrid. Revista de Obras Públicas 1941; 1714: 213221. [In Spanish]

[29] Torroja E. Hipódromo de La Zarzuela, La Zarzuela Hippodrome. Informes de la Construcción 1962; 137. [In Spanish]

[30] Fernández-Troyano L, Cuervo J, Junquera J, Santana C, Vallier M, Delgado J, Muñoz G, Madrid M. Restauración y Rehabilitación del Hipódromo de la Zarzuela de Madrid. Restauration and Rehabilitation of Madrid's La Zarzuela Hippodrome, In Actas del V Congreso de la Asociación Científico-Técnica del Hormigón Estructural (ACHE), ACHE, Madrid, 2011. [In Spanish] 
[31] Castillo A, Andrade C, Martinez I, Rebolledo N, Fernandez-Troyano L, Ayuso G, Cuervo J, Junquera J, Santana C, Delgado J. Evaluacion y monitorizacion de la durabilidad de las cubiertas del Hipodromo de la Zarzuela de Madrid. Assessment and monitoring of durability of shell structures in "Zarzuela Racecourse". Informes de la Construcción 2011; 63(524): 33-41. [In Spanish]

[32] Desideri P, Nervi PL, Positano G. Pier Luigi Nervi. Zanichelli, Bologna, 1979.

[33] Payá-Zaforteza I. On the development of structural criticism through case studies, In: Proc. of the IABSE Symposium, IABSE, Venice, 2010 pp. 16-23.

[34] Lapunzina A. Architecture of Spain,Greenwood Publishing Group,Post Road West, Westport, 2005.

[35] Fundación Docomomo Ibérico, Equipamientos II. Ocio, deporte, transporte y turismo: Registro Docomomo Ibérico, 1925-1965. Facilities I. Leisure, sports, transportation and tourism. Docomomo Ibérico Record, 1925-1965, Fundación Caja de Arquitectos-Fundación DOCOMOMO Ibérico, Barcelona, 2011. [In Spanish]

[36] Lahuerta JJ. Grandstand at the Race-course Zarzuela, In World Architecture 1900-2000: a critical mosaic, Volume 4. Edited by K. Frampton and V. Magnago.Springer, Wien New York, 1999.

[37] Polo C. Personal communication to the authors on a visit to La Zarzuela Racecourse held on October $8^{\text {th }} 2013$.

[38] Higgings N. Madrid re-opens October 23rd after a 9 year closure!, http://www.jockeysroom.com/msg20.htm (2005), accessed on June1st 2015 


\section{Figure captions and tables}

Figure 1. La Zarzuela Racecourse exterior views: (a) front view, (b) lateral view of the grandstand, (c) view from the grandstands

Figure 2. La Zarzuela Racecourse interior views

Figure 3. Proposals presented to La Zarzuela Racecourse design competition (adapted from Torroja [29])

Figure 4. Entry presented by Arniches, Domínguez and Torroja to La Zarzuela's design competition: (a) cross section (adapted from Torroja [29]), (b) 3D view of the roof structure

Figure 5. Basic structural solution proposed by Arniches, Domínguez and Torroja to solve the requirements of the design competition (adapted from Torroja [29])

Figure 6. Final solution: (a) cross section (adapted from Torroja [28]), (b) 3D view of a module of the roof structure

Figure 7. Simplified structural model used to analyze the stands structure. The point F must not have transversal displacement.

Figure 8. Definition of the roof by E. Torroja [29]: (a) lateral view and longitudinal section, (b) cross sections

Figure 9. Basic lobe used by E. Torroja to analyze, test and build the roof. Source: Torroja [29])

Figure 10. Location of the rebars in a lobe. Source: Torroja [28]

Figure 11. Experimental test of a full-scale lobe (source: Archivo Torroja)

Figure 12. (a) Works on the tie member to exam its condition, (b) repairing works on one lobe. Author of the images: G. Ayuso

Table 1. Volume of concrete and surface of formwork required to build one module of the roof according to Fernández-Casado's proposal, Torroja's initial design and Torroja's final design 


\section{Table 1}

Volume of concrete and surface of formwork required to build one module of the roof according to Fernández-Casado's proposal, Torroja's initial design and Torroja's final design.

\begin{tabular}{|c|c|c|c|c|c|c|}
\hline \multirow[b]{2}{*}{ Element } & \multicolumn{3}{|c|}{ Volume of concrete $\left(\mathrm{m}^{3}\right)$} & \multicolumn{3}{|c|}{ Surface of formwork $\left(\mathrm{m}^{2}\right)$} \\
\hline & $\begin{array}{l}\text { Fernánde } \\
\text { z-Casado }\end{array}$ & $\begin{array}{c}\text { Torroja's initial } \\
\text { design }\end{array}$ & $\begin{array}{l}\text { Torroja's } \\
\text { final } \\
\text { design }\end{array}$ & $\begin{array}{l}\text { Fernández- } \\
\text { Casado }\end{array}$ & $\begin{array}{c}\text { Torroja's } \\
\text { initial design }\end{array}$ & $\begin{array}{c}\text { Torroja's } \\
\text { final design }\end{array}$ \\
\hline $\begin{array}{c}\text { Cantilever } \\
\text { beams }\end{array}$ & 4,5 & 4,8 & - & 60 & 45 & - \\
\hline $\begin{array}{c}\text { Stiffening } \\
\text { beams }\end{array}$ & 4,8 & - & - & 39 & - & - \\
\hline Ribs & - & 0,53 & - & - & 11 & - \\
\hline Roof slab & 4,4 & 6,01 & 12 & 73 & 100 & 106 \\
\hline Total & 13,7 & 11,34 & 12 & 172 & 156 & 106 \\
\hline $\begin{array}{c}\text { Total per } \\
\text { linear meter } \\
\text { of } \\
\text { grandstand }^{1}\end{array}$ & 3,04 & 2,27 & 2,40 & 34,4 & 31,2 & 21,2 \\
\hline $\begin{array}{l}{ }^{1} \text { Fernández-C } \\
\text { quantities of } \\
\text { obtain compa }\end{array}$ & $\begin{array}{l}\text { do places } \\
\text { rete and } \\
\text { e values. }\end{array}$ & $\begin{array}{l}\text { ortal frames } \\
\text { nwork have }\end{array}$ & $\begin{array}{l}4,5 \mathrm{~m} \\
\text { divided }\end{array}$ & Torroja e & $\begin{array}{l}5 \mathrm{~m} \text {. Ther } \\
\text { ween two }\end{array}$ & $\begin{array}{l}\text { re, the total } \\
\text { tal frames to }\end{array}$ \\
\hline
\end{tabular}




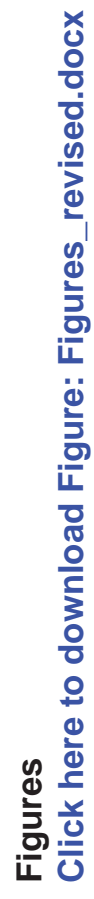

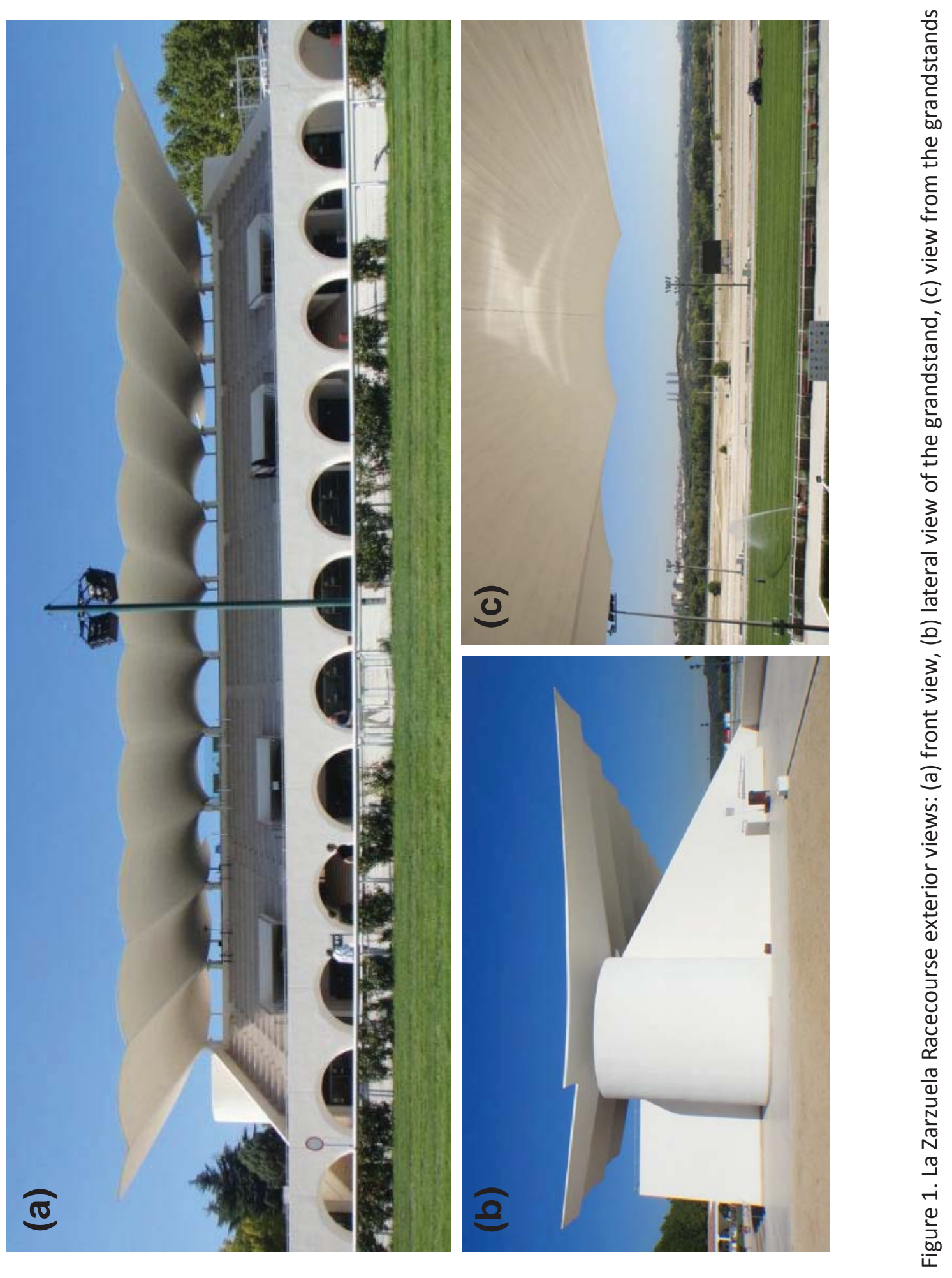




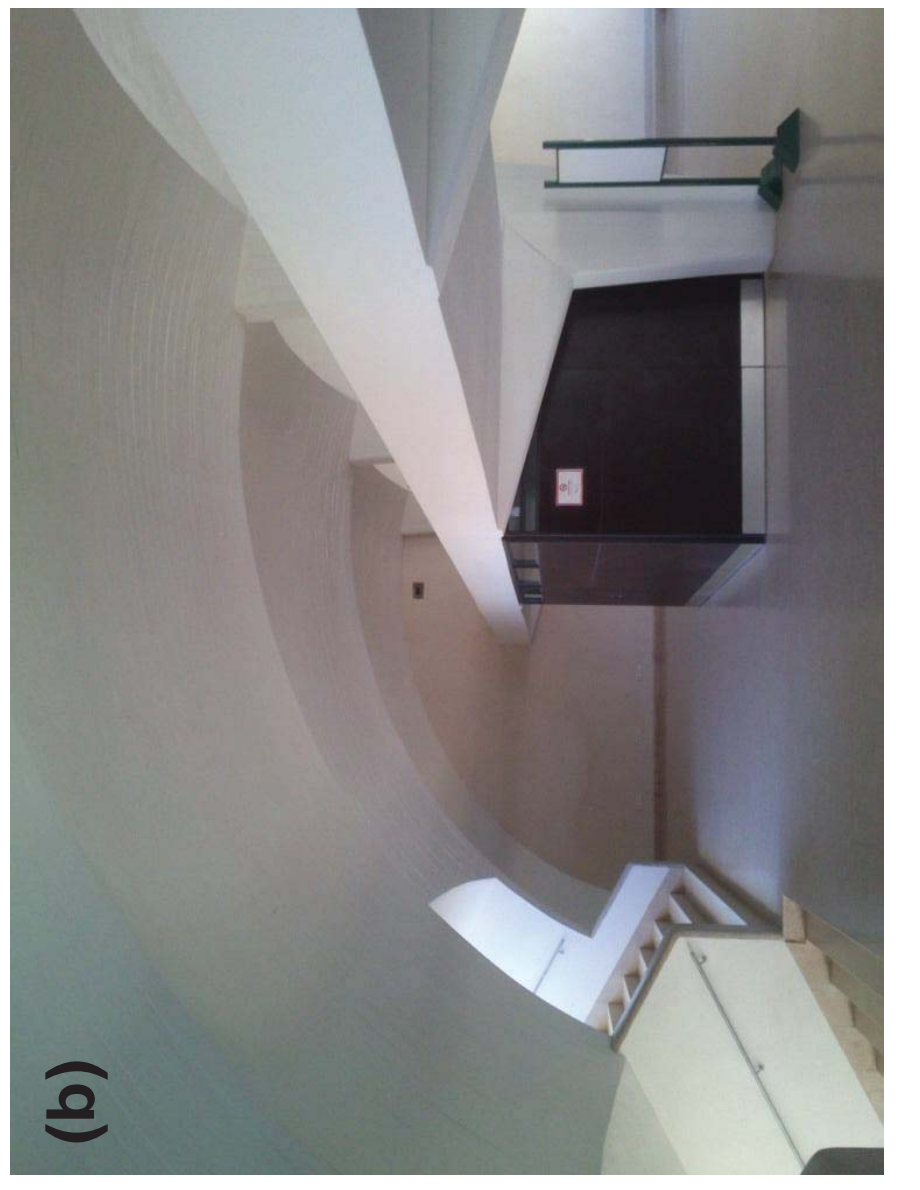

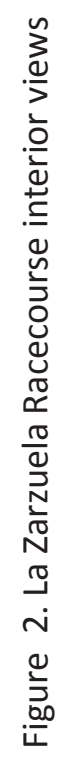



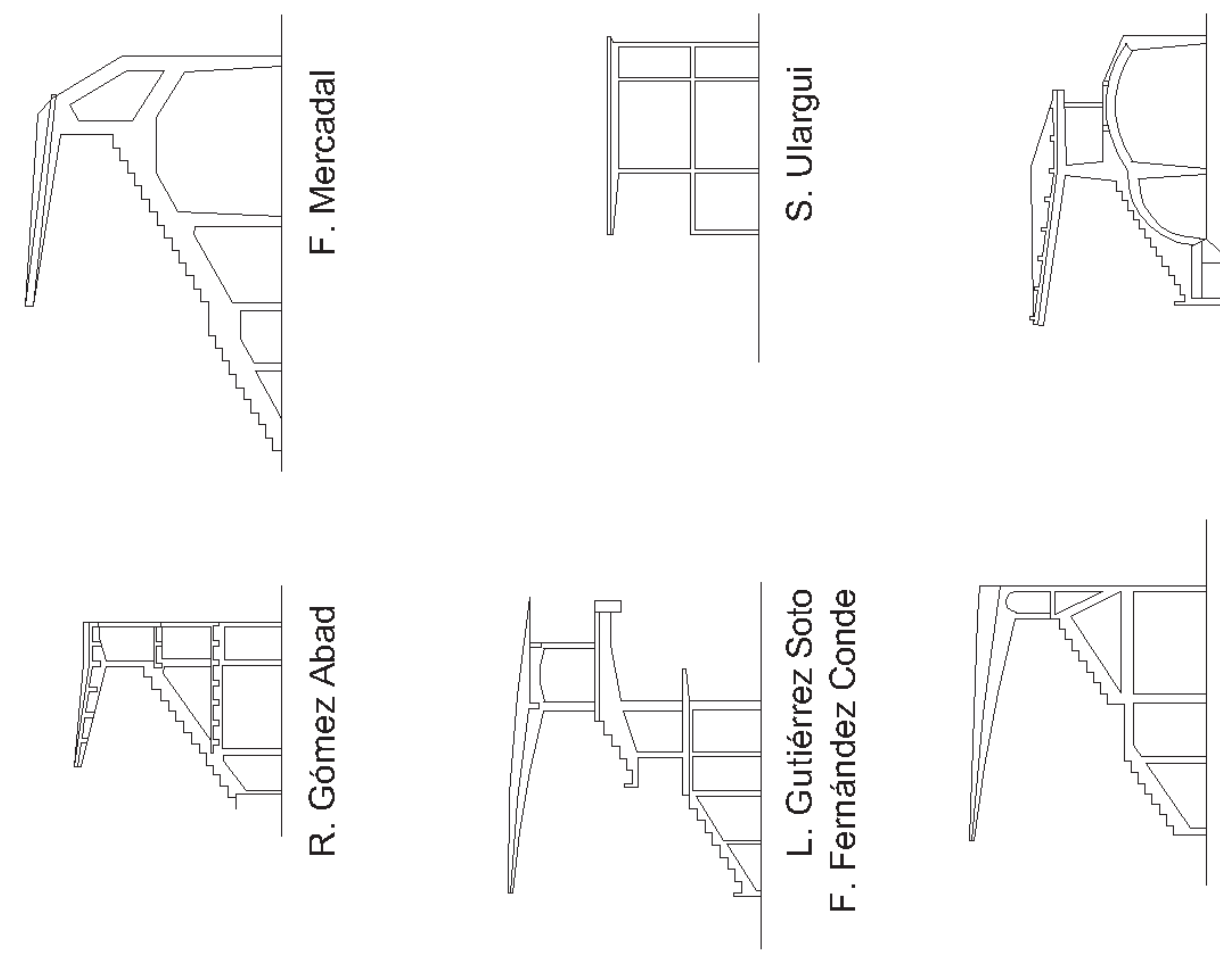

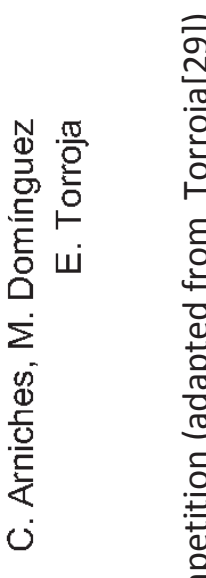

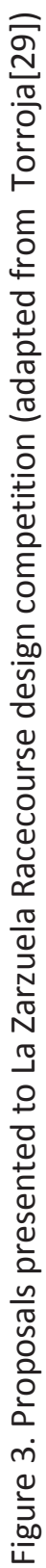

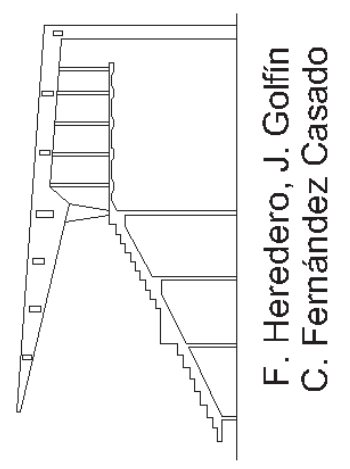

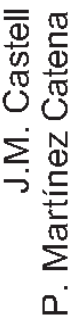

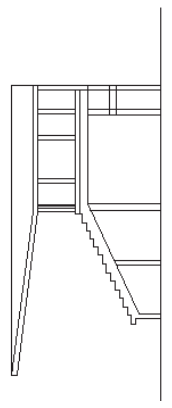

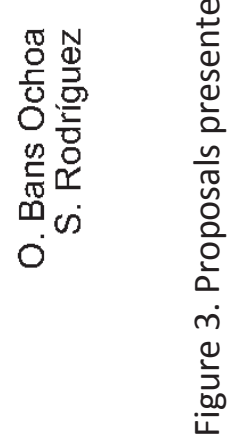

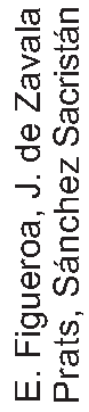

$\pi$

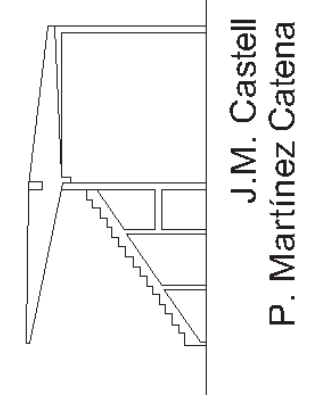




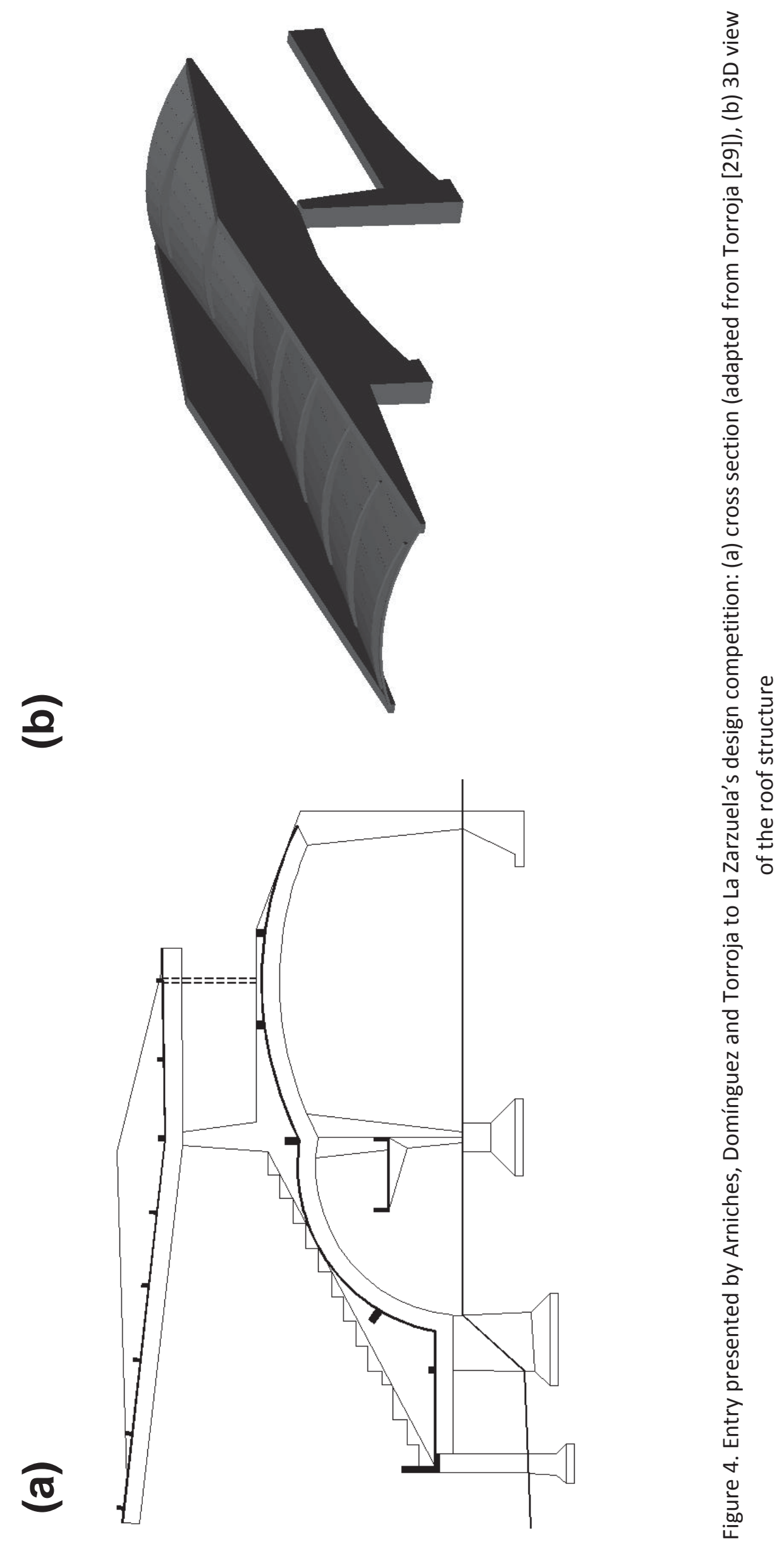




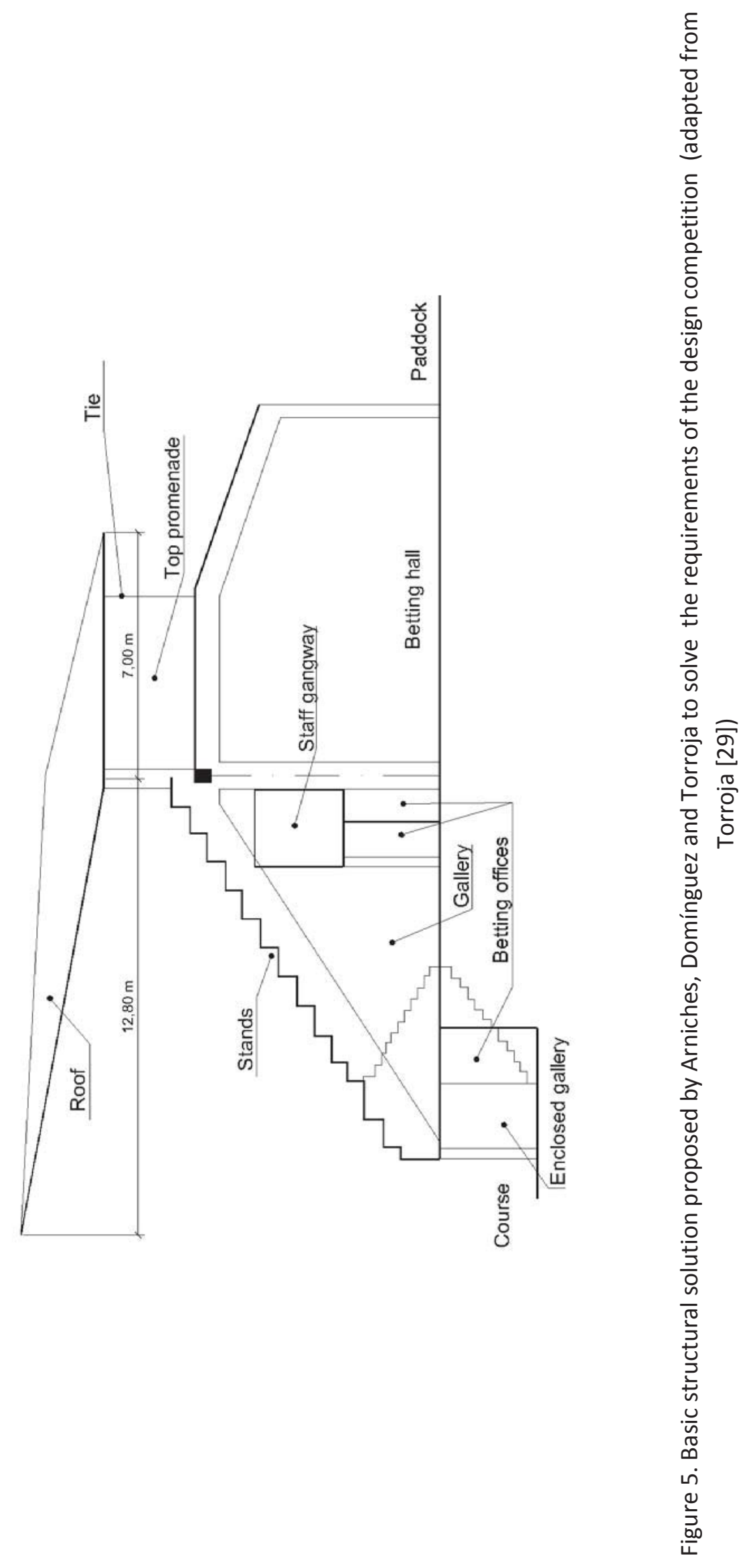




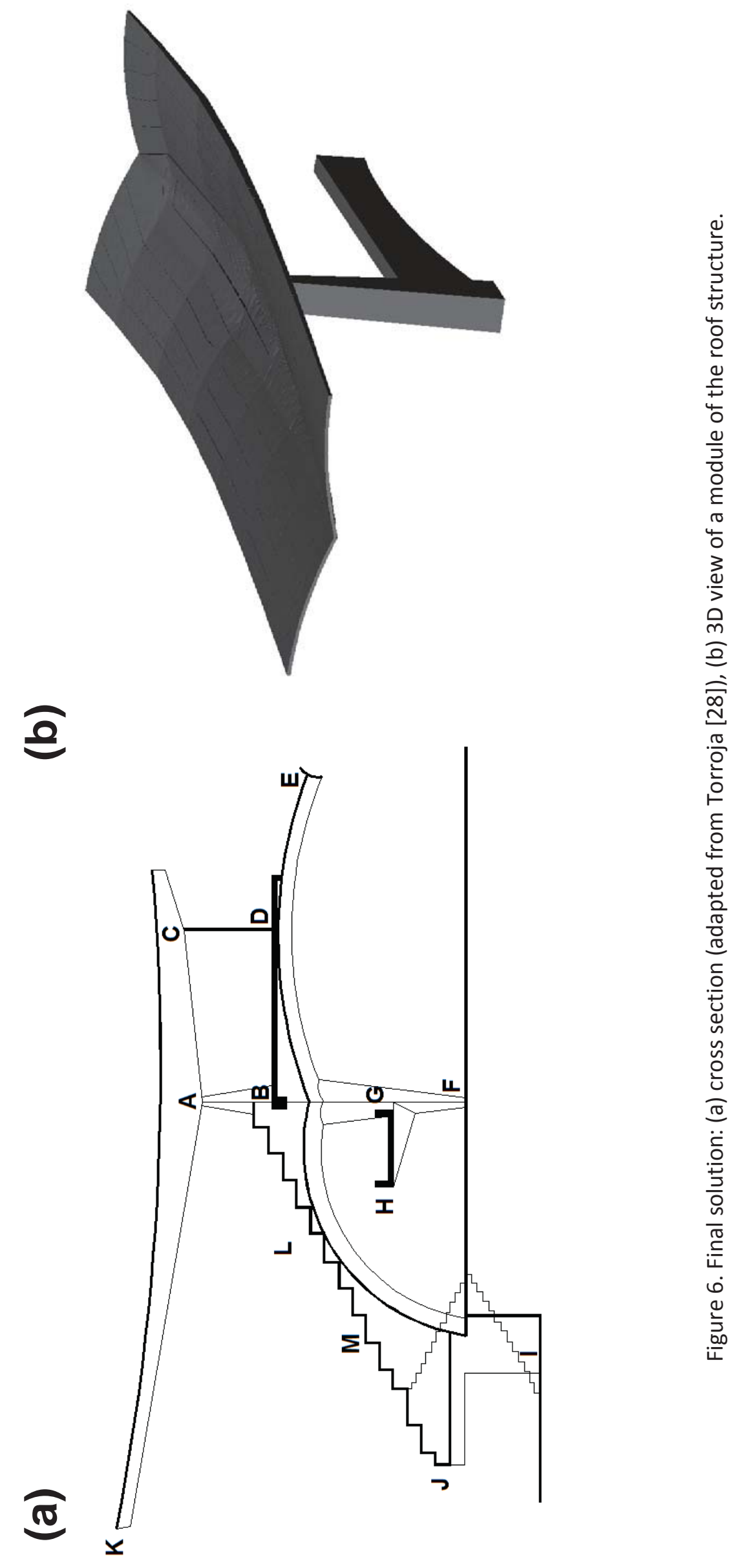




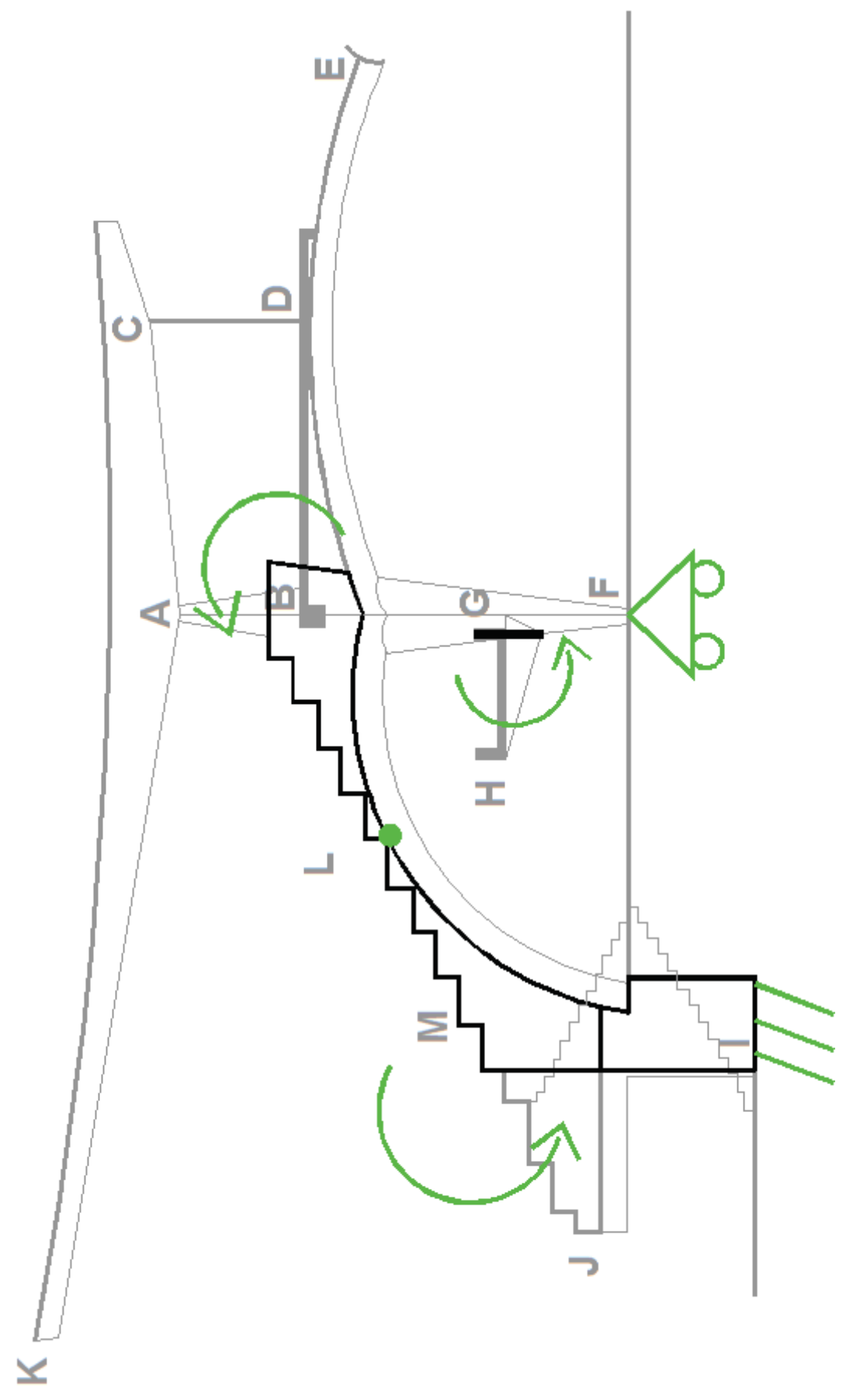

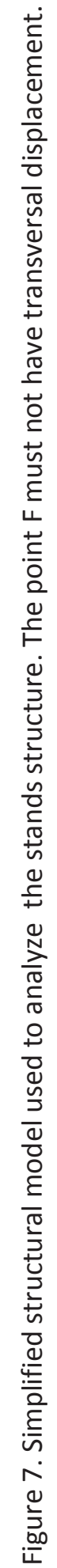




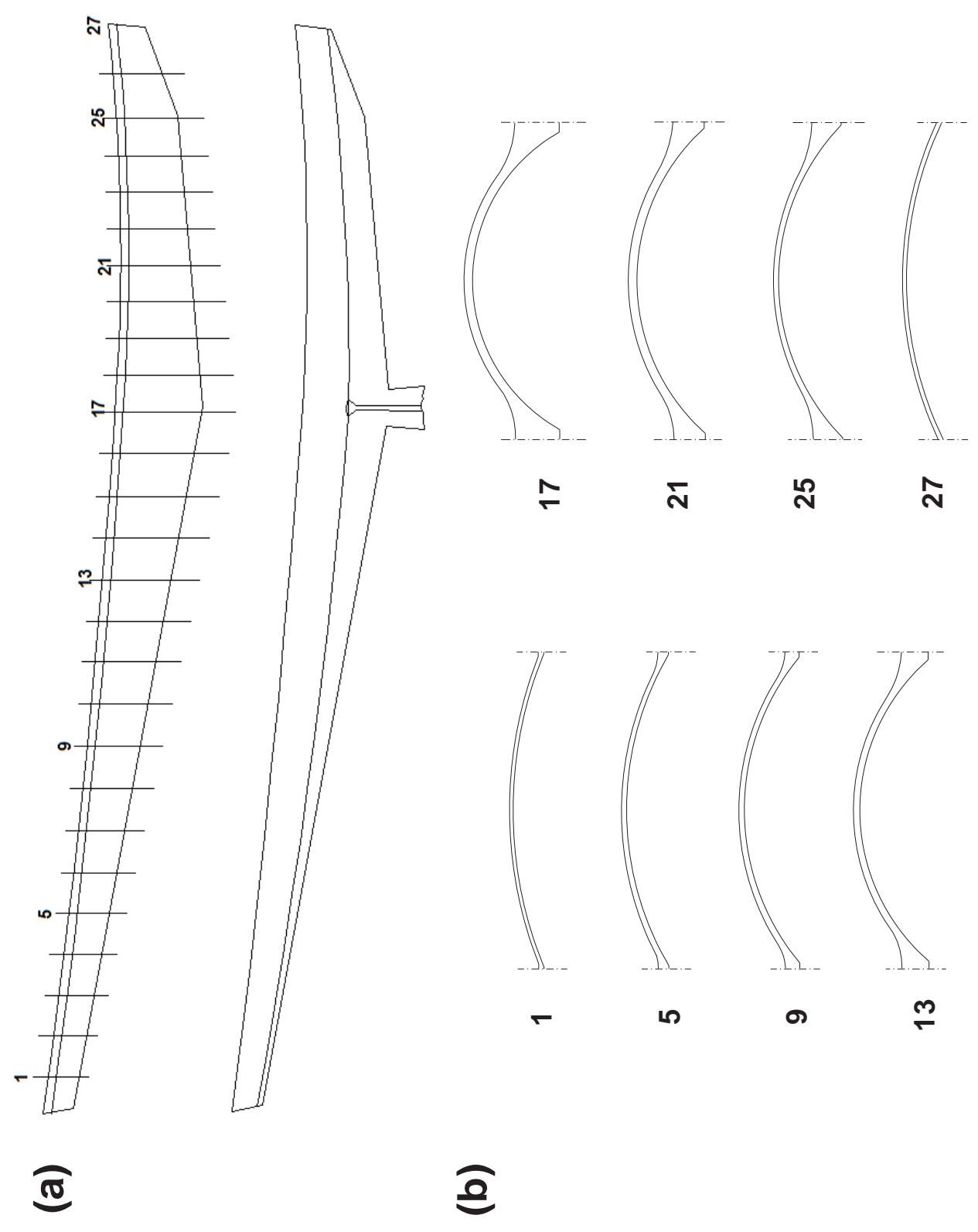

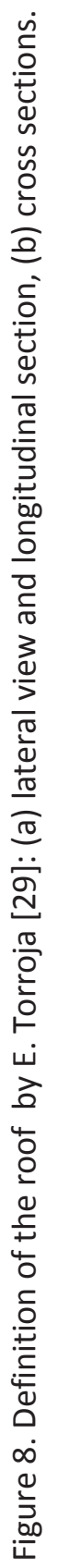




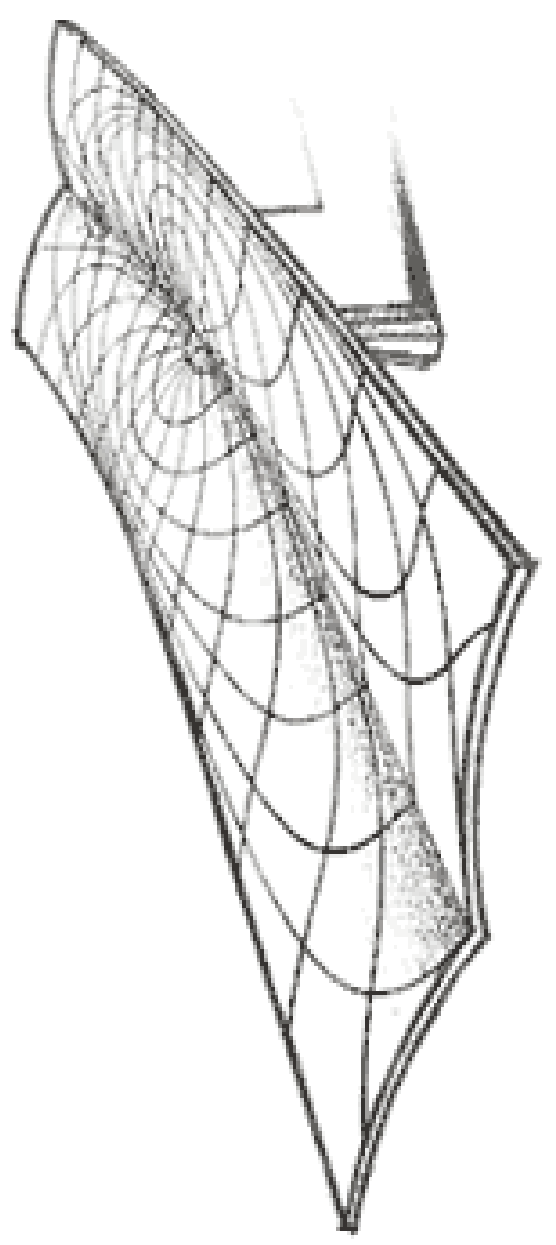

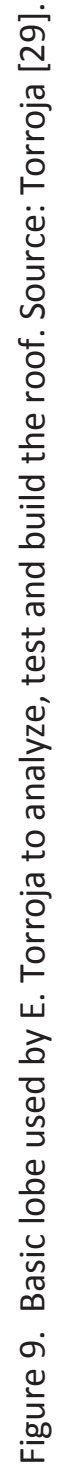




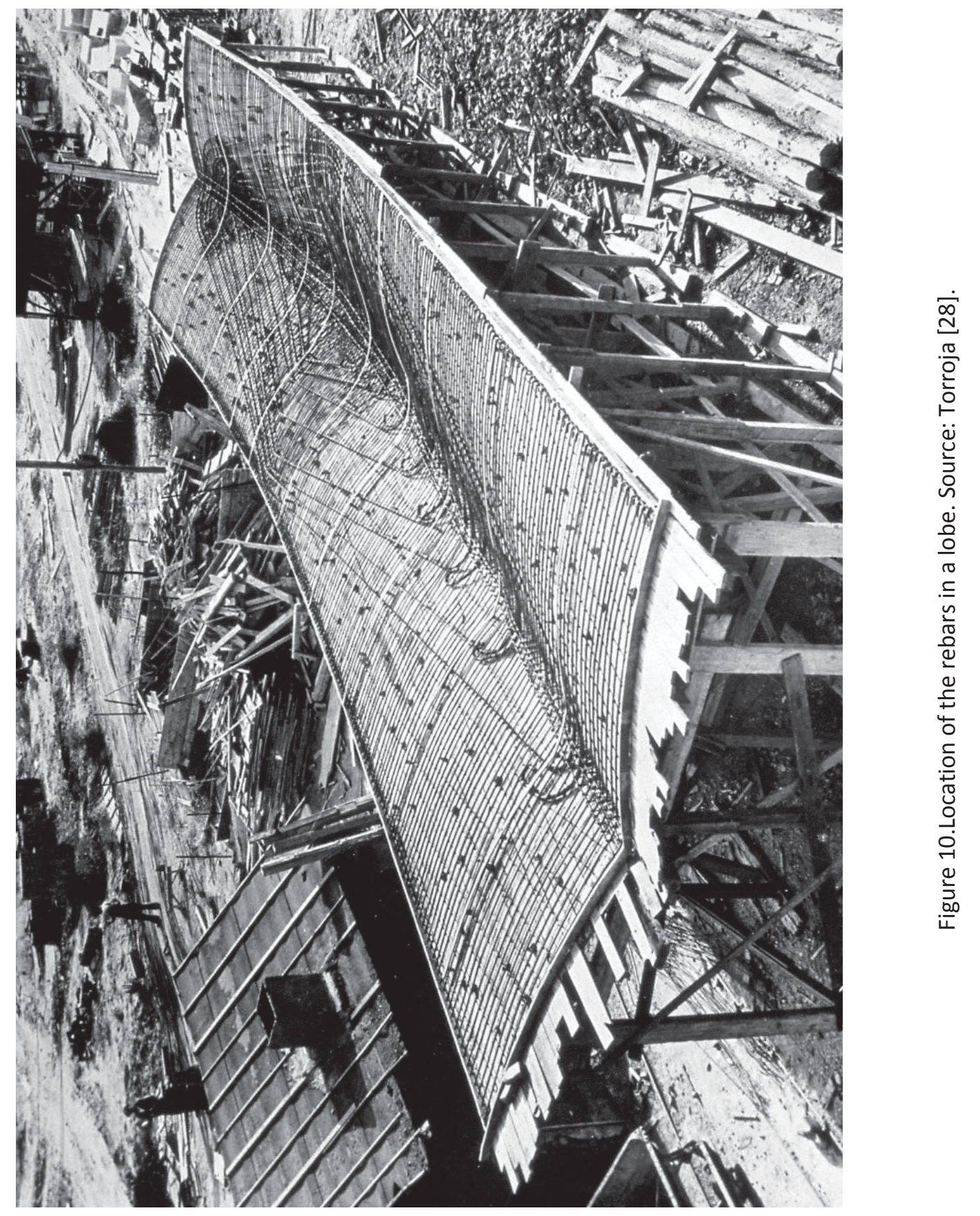




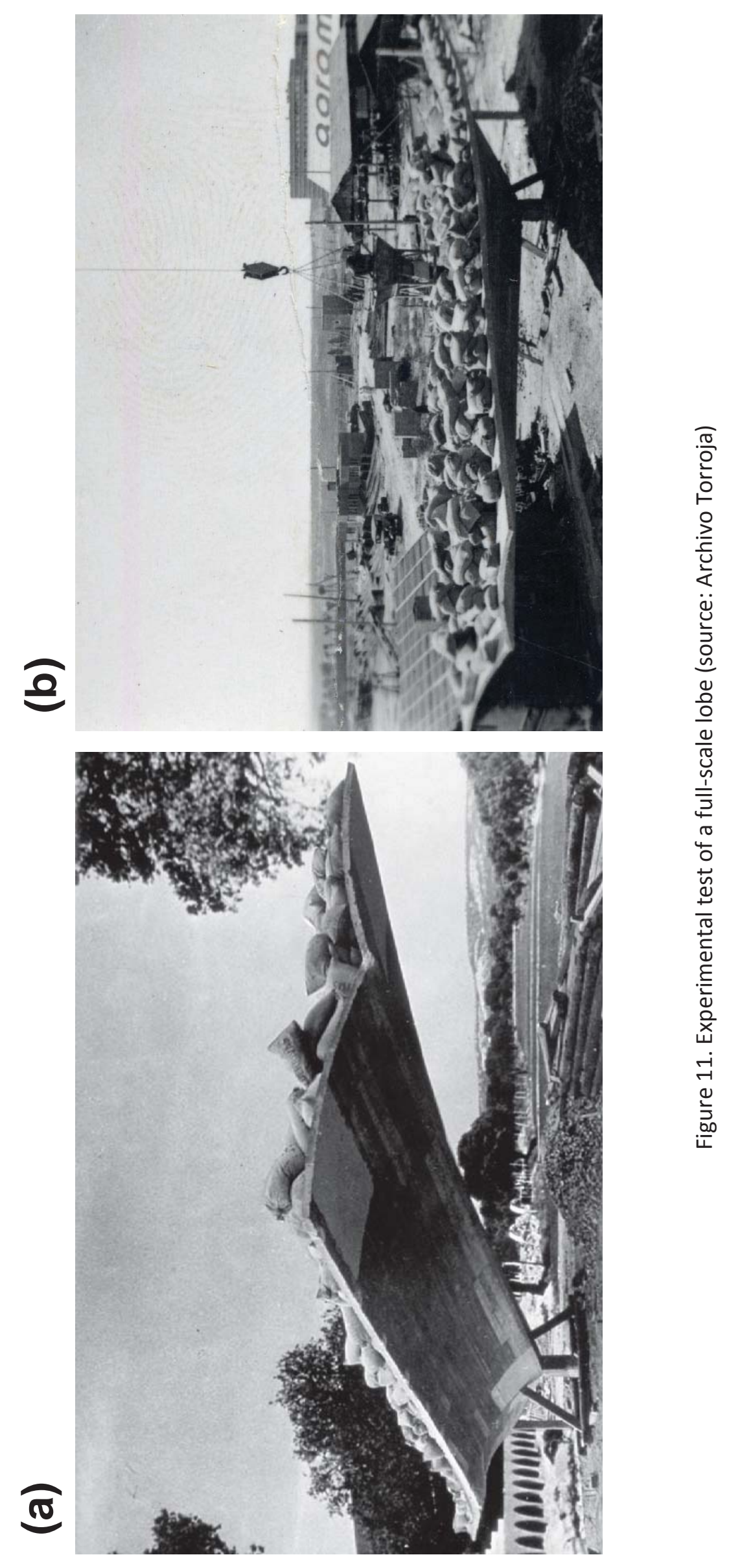




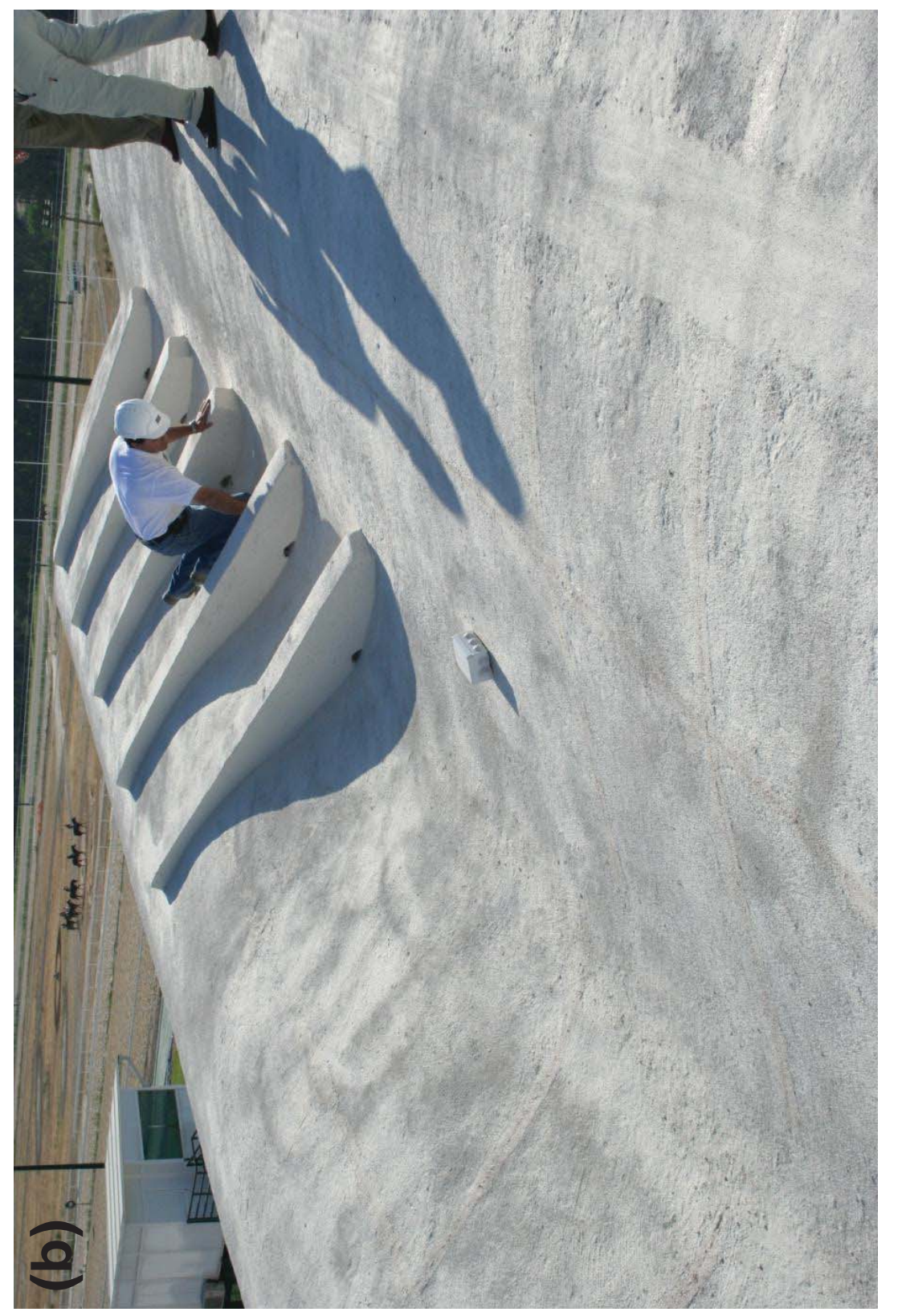

产

$\ddot{d}$

$\stackrel{20}{\Xi}$

孚

$\circ$

旁

هั

음

ธ

ธ

ำ

3

$\stackrel{\text { 을 }}{=}$

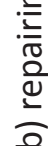

?

오ำ

풍

$\stackrel{\infty}{.}$

๕

,

$\stackrel{+}{\bar{\nu}}$

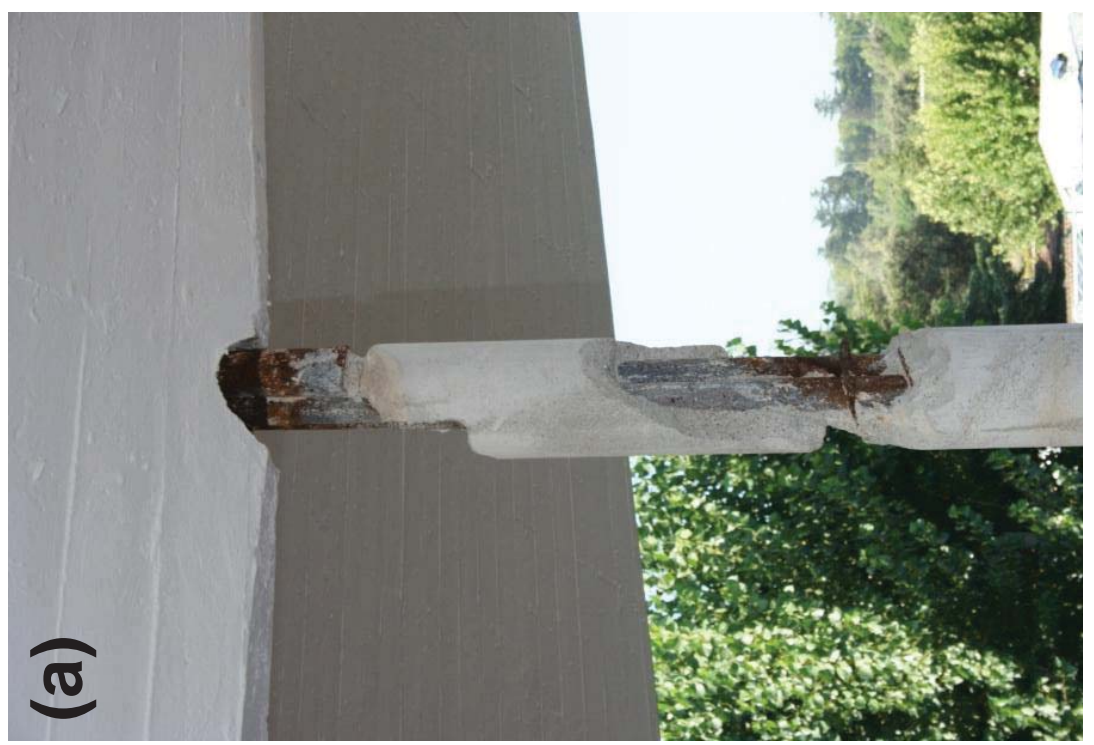

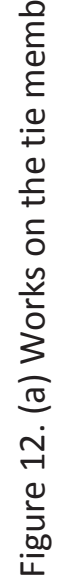

